\title{
INTERNSHIPS AND THE NEXT GENERATION OF PHARMACISTS IN ROMANIA
}

\author{
CĂTĂLINA LILIANA ANDREI ${ }^{1}$, DRAGOS FLORIAN CIOLAN ${ }^{2 *}$, ANDREEA MIRICA ${ }^{3}$, IULIA \\ ELENA TOMA ${ }^{3}$, DOINA DRĂGĂNESCU ${ }^{4}$, FLAVIAN ȘTEFAN RĂDULESCU $^{2}$
}

\author{
1 "Carol Davila” University of Medicine and Pharmacy, Department of Cardiology and Thoracic Pathology, Bucharest, Romania \\ 2 "Carol Davila" University of Medicine and Pharmacy, Center for Drug Sciences (CedS), Bucharest, Romania \\ ${ }^{3}$ Bucharest University of Economic Studies, Faculty of Economic Cybernetics, Statistics and Informatics, Statistics and \\ Econometrics Department, Bucharest, Romania \\ 4 "Carol Davila” University of Medicine and Pharmacy, Department of Pharmaceutical Physics and Informatics, Bucharest, \\ Romania
}

*corresponding author: dragos.ciolan@yahoo.com

Manuscript received: September 2018

\begin{abstract}
The pharmacy profession in Romania has undergone several structural transformations. The role of pharmacists has changed and there are many career possibilities. In this context, students must prepare themselves as well as possible in order to make the transition from school to work. Internships play a crucial role in this process. This paper analyses students' perception with regard to internships and proposes an instrument for an in-depth examination of such activities. The analysis was performed using the multinomial regression technique.
\end{abstract}

\section{Rezumat}

Profesia de farmacist a cunoscut mai multe transformări de ordin structural. Rolul farmacistului s-a schimbat, existând mai multe posibilități în alegerea carierei. În acest context, studenții trebuie să se pregătească cât mai bine pentru a realiza tranziția de la școală la viață activă. Lucrarea de față analizează percepția studenților cu privire la activitățile de internship și propune un instrument de explorare în detaliu a acestor activități. Analiza datelor este realizată cu ajutorul metodei regresiei multinomiale.

Keywords: internship, pharmacy, multinomial regression

\section{Introduction}

Nowadays, pharmacists have a wide variety of responsibilities, that do not necessarily align with their traditional tasks (preparing, obtaining, storing, securing, distributing, dispensing and disposing of medical products), but rather involve contributing to the effectiveness and efficiency of the health-care system and public health [25]. In this respect, the pharmacist, as a bridge between researcher, manufacturer, prescriber and patient, is also communicator, decisionmaker, caregiver, manager, life-long learner, teacher, leader and researcher [26]. Moreover, there are five major pharmaceutical care practice domains a pharmacist can enter: risk management (includes adverse effects reporting, documenting therapeutic interventions, calculating dosages), patient advocacy (involves eliminating possible barriers to proper drug therapy), disease management (involves providing relevant information to patients in order to ameliorate their condition), pharmaceutical care service marketing (includes meeting prescribers and producers) and business management [4].
The role of pharmacists is also defined by the economic environment. In developing countries, pharmacists often deal with lack of appropriate and high-quality drugs, irrational use of medicines [1], counterfeit medicines [19], lack of procedures and medical guidelines [12]. In developed countries, new regulations should be adopted and implemented in order to enhance professional independency of a pharmacists $[5,20]$. Given the variety of possibilities a pharmacy graduate has, the changing role of the pharmacists and its challenges, it is mandatory for the educational programmes in this area to adapt to this new environment [21]. In order to prepare students for the pharmacy profession of the future new internships, based on reflection, communication and analytical skills must be integrated into the curriculum [21, 22]. Developing critical thinking is one of the essential elements for enhancing students' reflective abilities [17]. With regard to the specific activities that should be implemented during internships, there is a consensus between students and tutors that in order to develop all the desired skills, one needs to combine formal and informal learning activities [24]. Tutors must play an active role in designing the curriculum, including 
the outcomes of students' internship activities and ensure the later are trained adequately [8].

The research conducted and reported in the current article ensures the sustainability of SOPARD/161/ 2.1/G/141846 Project [17], developed by the "Carol Davila" University of Medicine and Pharmacy Bucharest, Romania. During the implementation of this Project, the activities with the students (the same Target Group involved also in the present research) were materialized in developing the Career Counselling and Practice Guides. The aim of the present study was to develop the premises and the context for a "survey" of students and graduates from the Faculty of Pharmacy in Bucharest, Romania. This "survey" was developed taking into consideration the European Commission Council Recommendation on tracking graduates [7].

\section{Materials and Methods}

In order to achieve this objective, a short questionnaire (Figure 1) was distributed to students participating in projects that aim to provide internship opportunities. Firstly, we assessed, on a five points ascending scale, the extent to which internships help the respondent make a decision about his/her future career, discover his/her abilities and gather more information about the future professional possibilities.

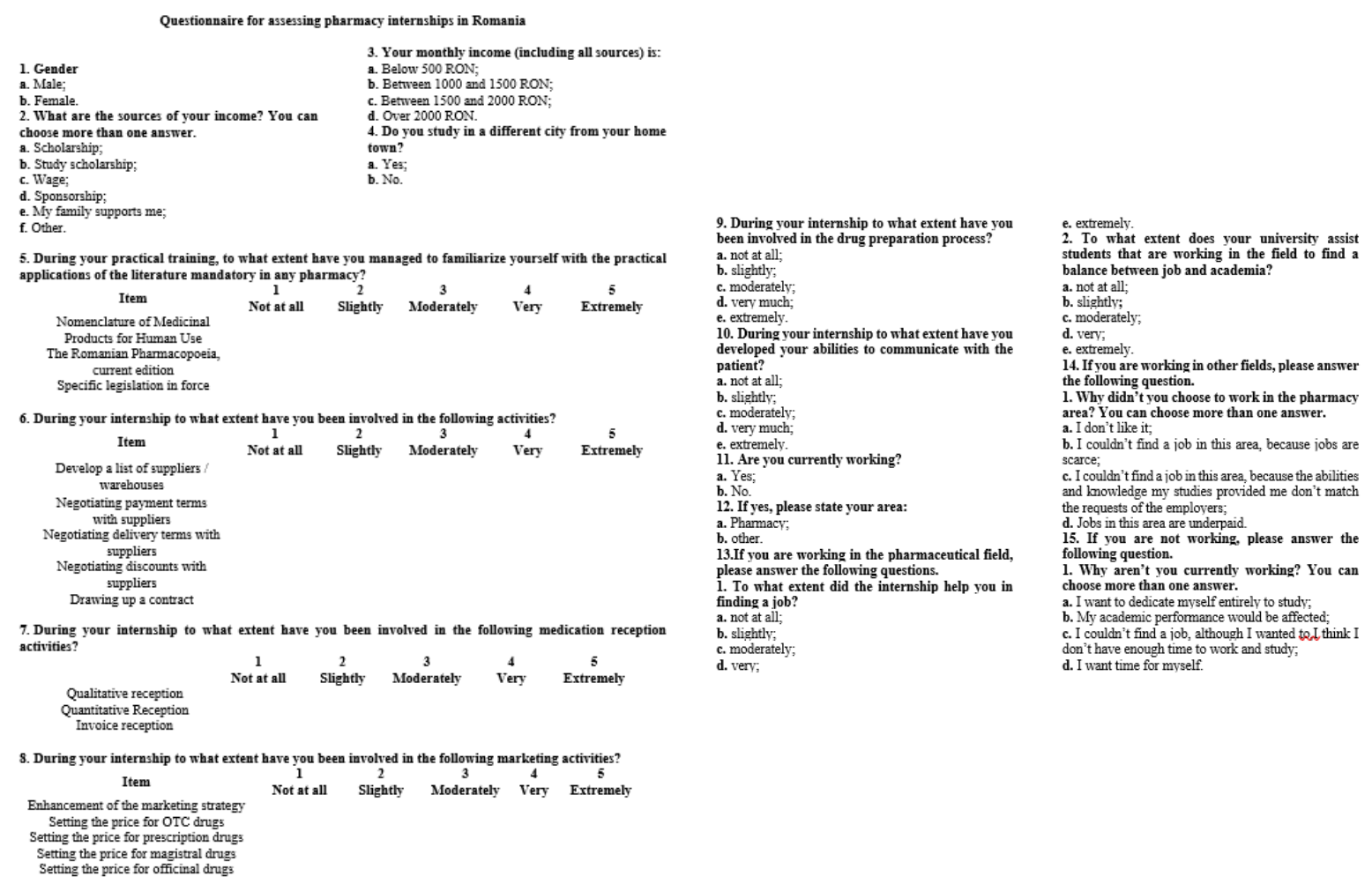

Figure 1

Questionnaire for assessing pharmacy internship in Romania

These are variables $\mathrm{V} 1, \mathrm{~V} 2$ and $\mathrm{V} 3$ respectively. Secondly, we assessed, on a five points ascending scale, the extent to which the respondents believes that the activity he/she participated in, would also help other pharmacy students (variable V4). Thirdly, we assessed, on a five points ascending scale, the extent to which the respondents would recommend implementing such activities for other students (variable V5). 259 pharmacy students responded to our call. Spearman correlation coefficient was used for the purpose of evaluating whether or not there is a link between these variables. Next, the answers were recoded into two categories as follows: for variables $\mathrm{V} 1, \mathrm{~V} 2$ and $\mathrm{V} 3$ points 1 to 3 on the scale were given the value 3 meaning that "the internship program rather didn't help me achieving the desired objective". Points 4 and 5 on the scale were given the value 4 meaning that "the internship program rather helped me to achieve the desired objective"; for variable V4, points 1 to 3 on the scale were given the value 3 meaning that "the internship program rather doesn't help other students". Points 4 and 5 on the scale were given the value 4 meaning that "the internship program rather helps other students"; for variable V5, points 1 to 3 on the scale were given the value 3 meaning that "I would rather don't recommend such programs". Points 4 and 5 on the scale were given the value 4 meaning that "I would rather recommend such programs".

Using these new categories, a multinomial regression was performed in order to explore the influence of variables V1, V2 and V3 on V4 and V5, respectively. 
FARMACIA, 2019, Vol. 67, 2

Considering that: the response variable V5 has 2 categories (category 3 and 4) and there are 3 explanatory variables within the model; $v 5_{i}=$ $\left(v 5_{i 1}, v 5_{i 2}\right)$ are the response values in i-th subgroup having multinomial distribution $M n\left(n_{i}, p_{i 1}, p_{i 2}\right)$; $\beta_{3}=\left(\beta_{03}, \beta_{13}, \beta_{23}, \beta_{33}\right)^{\prime}$ are regression coefficients for category 3 with respect to category 4 (reference category); $v_{i}=\left(1, v_{i 1}, v_{i 2}, v_{i 3}\right)^{\prime}$ are actual values of explanatory variables for the $i$-th subgroup; then, the model, with the dependent variable V5, is as follows:

$$
\log \left(\frac{p_{i 3}}{p_{i 4}}\right)=v_{i}^{\prime} \beta_{3}, \quad i \neq j,
$$

The second model, with V4 as a dependent variable is similar. A general description of the multinomial model was presented previously by Zezula I [27].

\section{Results and Discussion}

$89 \%$ of the respondents would recommend the implementation of projects that aim to provide internship programs to students. Moreover, $86 \%$ of the respondents consider that internships like the ones they participated in, would help other pharmacy students. Approximately $80 \%$ of the students believe that the internships helped them make a decision with regard to their career, assess their abilities and know their future professional possibilities. Figure 2 and Figure 3 display these results.

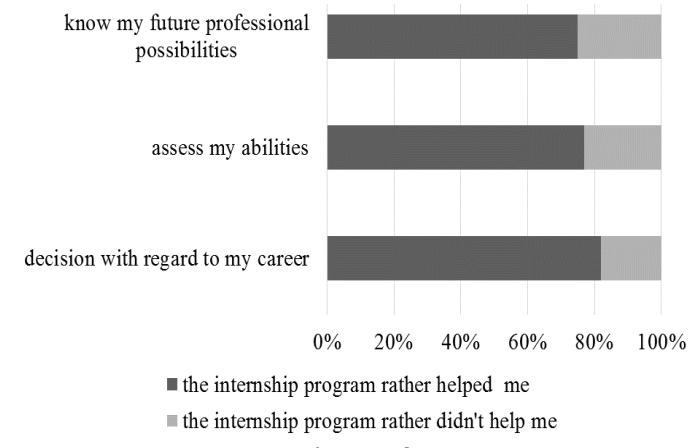

Figure 2.

Research results with regard to the independent variables; source: designed by the authors based on data collected through questionnaire
I would rather recommend such programs



The internship program rather helps other students

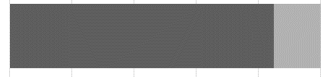

$\begin{array}{llllll}0 \% & 20 \% & 40 \% & 60 \% & 80 \% & 100 \%\end{array}$

Yes $\square$ No

Figure 3.

Research results with regard to the dependent variables; source: designed by the authors based on data collected through questionnaire

Table I presents the correlation coefficients between variables V1 to V5. As one can observe, all coefficients are positive and significant indicating a medium correlation.

Table I

Spearman correlation coefficient between variables V1 to V5, source: designed by the authors, based on data collected through questionnaire

\begin{tabular}{|c|c|c|c|c|}
\hline Variables & V2 & V3 & V4 & V5 \\
\hline V1 & $0.63^{*}$ & $0.57^{*}$ & $0.59^{*}$ & $0.48^{*}$ \\
\hline V2 & 1 & $0.65^{*}$ & $0.65^{*}$ & $0.53^{*}$ \\
\hline V3 & & 1 & $0.68^{*}$ & $0.58^{*}$ \\
\hline V4 & & & 1 & $0.72^{*}$ \\
\hline *ignificance level of 5\%
\end{tabular}

Table II presents the results of two multinomial regression models. Both models fit the data well: Pearson Chi-Square and Deviance Chi-Square are not significant. Moreover, in both cases the full model statistically significantly predicts the dependent variable better than the intercept-only model alone: Model fitting information Final Likelihood Ratio Chi-Square Test is significant. As one can observe from the results of model 1, students would recommend internship activities if such activities help them achieve the desired objectives: gathering information about professional opportunities, discovering their abilities and deciding about their future. Model two reveals that students are much aware that the value of the internship programs is given by the extent to which they help students develop.

Table II

Multinomial regression models results; source: designed by the authors, based on data collected through questionnaire

\begin{tabular}{|c|c|c|}
\hline & Model 1 & Model 2 \\
\hline Dependent variable & V5 & V4 \\
\hline Independent variable V1 & $1.333^{* *}($ std. err $=0.508)$ & $1.815^{*}($ std. err $=0.5)$ \\
\hline Independent variable V2 & $1.55^{*}($ std. err $=0.547)$ & $1.585^{*}($ std. err $=0.512)$ \\
\hline Independent variable V3 & $1.558^{*}($ std. err. $=0.535)$ & $1.99^{*}($ std. err $=0.51)$ \\
\hline $\begin{array}{c}\text { Model fitting information - Final Likelihood } \\
\text { Ratio Chi-Square Test (value and significance) }\end{array}$ & $57.591 *$ & $23.135^{*}$ \\
\hline
\end{tabular}

* significance level of 5\%; ** significance level of $10 \%$

The pharmacy profession in Romania has a long tradition, starting in the $13^{\text {th }}$ century [14]. Tertiary education programmes in pharmacy began in the $19^{\text {th }}$ century, facing many challenges [18]. After the Romanian Revolution in 1989 , when tertiary education programmes in pharmacy were already well established, 
several transformations occurred in this field. Firstly, the number of graduates in pharmacy was 13 times higher in 2013 compared to 1990 and has an ascending trend (Figure 4).



Figure 4.

Number of graduates in the medical field in Romania by type, data source: TEMPO Online database (retrieved $14^{\text {th }}$ July 2017)

The number of graduates in the human medical field, including dentistry, increased by $200 \%$ in the same period. Also, one must observe that the share of pharmacy graduates in the total number of medical graduates increased from 4\% in 1990 to $20 \%$ in 2013. Secondly, after 1990, private universities were established in Romania, leading to an increased competition in the pharmaceutical tertiary education. According to the data provided by the National Institute of Statistics Romania (retrieved $14^{\text {th }}$ July 2017), 35\% of the graduates in pharmacy in 2003 came from private universities. However, these universities proved to be less competitive compared to the public ones, as their share of graduates was only $9 \%$ in 2013. Thirdly, according to the most recent data published by Eurostat, Romania registers one of the highest numbers of pharmacy graduates per 100,000 inhabitants, more specifically 8.4 [10]. Moreover, according to the same source, only Portugal (12 graduates per 100,000 inhabitants) and Malta (10.2 graduates per 100,000 inhabitants) registered a higher value.

Several events occurred after 1989 on the labour market in the pharmaceutical field in Romania. Firstly, the harmonisation to EU norms in pharmacy training and practice lead to a massive brain drain of pharmaceutical graduates to other EU countries [16]. Secondly, the lack of personnel in this area leads to a high rate of prevalence of the burnout syndrome among employees [11]. Given the challenges pharmacists are facing and the complex situation of the pharmacy profession in Romania, it is mandatory for any student in this field to prepare as well as possible in order to have a smooth transition from school to the labour market. Internships are the key element linking school and labour market [2]. Therefore, it is very important that students are properly motivated to engage themselves into this activity.

\section{Conclusions}

The Pharmacy profession in Romania has undergone several structural transformations due to the changes in the role of pharmacists (demand side of the labour market) and the remodelling of the pharmacy higher education (supply side of the labour market). Both transformations raised several challenges for students in this field, out of which the most severe is gaining proper abilities and competencies to match employers' expectations.

Internships play a key role in overcoming these challenges. Our findings suggest that students know the importance of internships. Moreover, they are willing to engage themselves in such activities, but only as long as they contribute to their professional development. Our findings are similar to those in other eastern European countries such as Poland and Ukraine [9]. The research should be further extended by analysing to what extent students engage themselves in specific activities, further required on the labour market, during internships. The scientific literature offers several insights in this respect: getting familiar with the legislative changes that are occurring in the field [3], using modern marketing instruments for promoting medicines [15], using adequate communication strategies in order to best satisfy patient needs [13]. Based on these findings we propose a questionnaire that can be used to perform a more in-depth analysis on pharmacy internships in Romania.

\section{Acknowledgement}

This work was financially supported by SOPARD: Career counselling and career guidance for pharmacists SOPARD/161/2.1/G/141846

\section{References}

1. Azhar S, Hassali MA, Ibrahim MIM, Ahmad M, Masood I, Shafie AA, The role of pharmacists in developing countries: the current scenario in Pakistan. Hum Res Health, 2009; 7(1): 1-6.

2. Crnković-Pozaić S, Transition from school to work: Internships and first entry to the labour market in Croatia, 2006; www.etf.europa.eu.

3. Crisan $\mathrm{O}$, Good pharmacy practice in the context of cross-border healthcare. Farmacia, 2017; 65(2): 310316.

4. Desselle S, The pharmacist and pharmacy profession, 2017; www.jblearning.com.

5. Dawoud D, Griffiths P, Maben J, Goodyer L, Greene $\mathrm{R}$, Pharmacist supplementary prescribing: A step toward more independence?. Res Social Admin Pharmacy, 2011; 7(3): 246-256.

6. Drăgănescu D, Ciolan DF, Dumitrescu IB, Counseling and career orientation of a pharmacist human resource development project dedicated to pharmacies students in Bucharest. Farmacist.ro, 2015; 12(162-2): 38. (available in Romanian). 
7. European Commission Council recommendation on tracking graduates, 2017; www.europarl.europa.eu.

8. FIP statement of policy on Good Pharmacy Education Practice; www.fip.org.

9. Govorukha M, Hulchiy O, Adauji S, Pharmaceutical management training: Multistage research in Poland and Ukraine. Farmacia, 2016; 64(6): 953-959.

10. Healthcare personnel statistics - dentists, pharmacists and physiotherapists, http://ec.europa.eu.

11. Iorga M, Dondas C, Sztankovszky LZ, Antofie I, Burnout syndrome among hospital pharmacists in Romania. Farmacia, 2018; 66(1): 181-186.

12. Laing RO, Hogerzeil HV, Ross-Degnan D, Ten recommendations to improve use of medicines in developing countries. Health Policy Plan., 2001; 16(1): 13-20.

13. Minarikova D, Malovecka I, Foltan V, Patient choice of pharmacy and satisfaction with pharmaceutical care - Slovak regional comparison. Farmacia, 2016; 64(3): 473-480.

14. Pharmacy within the Romanian historical territories, www.colegfarm.ro. (available in Romanian).

15. Radu AV, Tascu AV, Stoica I, Radu AC, Purcarea VL, Online instruments used in pharmaceutical marketing. Farmacia, 2017; 65(2): 317-322.

16. Sandulovici R, Mircioiu C, Rais C, Atkinson J, Pharmacy practice and education in Romania. Pharmacy (Basel), 2018; 6(1): 1-13.

17. SOPARD/161/2.1/G/141846 Grant. Career counselling and career guidance for pharmacists, http://cofarm.ro (available in Romanian).
18. Stancu E, On the history of the interwar Romanian pharmacy, 2018; http://noema.crifst.ro. (available in Romanian).

19. Stenson B, Syhakhang L, Eriksson B, Tomson G, Real world pharmacy: assessing the quality of private pharmacy practice in the Lao People's Democratic Republic. Soc Sci Med., 2001; 52(3): 393-404.

20. Świeczkowski D, Merks P, Cwalina N, Jaguszewski MJ, Development of pharmacy practice in European countries - The Polish perspective. Pharmacy (Basel), 2017; 5(3): 1-8.

21. Wallman A, Pharmacy internship: Students' learning in a professional practice setting. Doctoral dissertation, Acta Universitatis Upsaliensis, 2010.

22. Wallman A, Lindblad AK, Hall S, Lundmark A, Ring $\mathrm{L}$, A categorization scheme for assessing pharmacy students' levels of reflection during internships. Am $J$ Pharm Educ., 2008; 72(1): 1-10.

23. Wallman A, Lindblad ÅK, Gustavsson M, Ring L, Factors associated with reflection among students after an advanced pharmacy practice experience (APPE) in Sweden. Am J Pharm Educ., 2009; 73(6): 1-11.

24. Wallman A, Gustavsson M, Lindblad ÅK, Ring L, An exploration of how students learn in a pharmacy internship. Pharm Educ., 2011; 11(1): 177-182.

25. World Health Organization. Joint FIP/WHO guidelines on good pharmacy practice: standards for quality of pharmacy services, 2011; http://apps.who.int.

26. World Health Organization. Developing pharmacy practice. A focus on patient care, 2006; www.fip.org.

27. Zezula I, Logistic, multinomial, and ordinal regression. Presentation at Robust 2010, Kralıky, 31.01.201005.02.2010; www.karlin.mff.cuni.cz. 